Available online at http://jurnal.goretanpena.com/index.php/JSSR

\title{
PENGEMBANGAN BAHAN AJAR MENULIS TEKS PERSUASIF MELALUI PENDEKATAN SAINTIFIK PADA SISWA KELAS VIII SMP NEGERI 3 RANTAU UTARA
}

\author{
Yani Afriyanti Pane, Risnawaty, Yulia Arfianti \\ Program Pascasarjana Pendidikan Bahasa Indonesia \\ Universitas Muslim Nusantara Al Washliyah, Medan \\ e-mail: yaniafriyanti757@yahoo.com
}

\begin{abstract}
Teaching materials are one of the important elements that affect the success of the learning process. One of the teaching materials used in the learning process is in the form of a module. Scientific-based teaching materials are teaching materials that contain $5 M$ scientific stages including the stages of Observing, Questioning, Gathering Information, Reasoning, and Communicating. This development research was conducted to produce a product in the form of teaching materials for writing persuasive texts through a scientific approach for class VIII junior high school students. The research model used in this development is the Research and Development $(R \& D)$ Borg \& Gall development model. The research model includes (1) research and information gathering, (2) planning stage, (3) initial product development, (4) initial field trial, (5) main product revision, (6) field trial, (7) final product revision, (8) field implementation test, (9) final product revision, and (10) dissemination and implementation. Data collection techniques in this study used tests, questionnaires, and validation sheets. The data analysis technique used is descriptive analysis technique. According to Sugiyono (2016: 254) states that descriptive statistics are used to analyze data by describing or describing the data that has been collected as it is without intending to make conclusions that apply to the public or generalizations. The purpose of this research is the development of teaching materials to improve students' ability in writing persuasive texts to students.
\end{abstract}

Keywords: Development, Teaching Materials, Persuasive Texts, Scientific.

\begin{abstract}
Abstrak: Bahan ajar merupakan salah satu elemen penting yang mempengaruhi kesuksesan proses pembelajaran. Salah satu bahan ajar yang digunakan dalam proses pembelajaran yaitu berbentuk modul. Bahan Ajar berbasis saintifik merupakan bahan ajar yang didalamnya mengandung tahapan-tahapan saintifik 5M diantaranya tahapan Mengamati, Menanya, Mengumpulkan Informasi, Menalar, dan Mengkomunikasikan. Penelitian Pengembangan ini dilakukan untuk menghasilkan produk berupa bahan ajar menulis teks persuasif dengan melalui pendekatan Saintifik untuk siswa kelas VIII SMP. Model penelitian yang digunakan pada pengembangan ini adalah model pengembangan Reseacrh and Development (R\&D) Borg \& Gall. Model Penelitian tersebut meliputi (1) penelitian dan pengumpulan informasi, (2) tahap perencanaan, (3) Pengembangan produk awal, (4) uji coba lapangan awal, (5) revisi produk utama, (6) uji coba lapangan, (7) revisi produk akhir, (8) uji pelaksanaan lapangan, (9) revisi produk akhir, dan (10) diseminasi dan implementasi. Teknik pengumpulan data dalam penelitian ini menggunakan tes, angket, dan lembar validasi. Teknik analisis data yang digunakan adalah teknik analisis deskriptif. Menurut Sugiyono (2016:254) menyatakan bahwa statistik deskriptif yang digunakan untuk menganalisis data dengan cara mendeskripsikan atau menggambarkan data yang telah terkumpul sebagaimana adanya tanpa bermaksud membuat kesimpulan yang berlaku untuk umum atau generalisasi. Tujuan penelitian ini adalah pengembangan bahan ajar untuk meningkatkan kemampuan siswa dalam menulis teks persuasif pada siswa.
\end{abstract}

Kata kunci: Pengembangan, Bahan Ajar, Teks Persuasif, Saintifik. 
Available online at http://jurnal.goretanpena.com/index.php/JSSR

\section{PENDAHULUAN}

Menulis merupakan keterampilan berbahasa yang harus dikuasai siswa. Dengan menulis seseorang dapat mengungkapkan ide atau gagasan. Menulis memerlukan konsentrasi untuk mengeluarkan ide ide yang cemerlang dalam menulis teks persuasif. Teks persuasif adalah karya tulis yang disusun dengan tujuan untuk mengajak atau mempengaruhi para pembacanya agar mau mengikuti kemauan si penulis. Maemunah ( 2011:34).

Menurut Wijayanti, dkk. (2013:123) "menulis teks persuasif (Ajakan) adalah paragraf yang berisi unsur ajakan, himbauan, bujukan, atau saran kepada pembaca, persuasif mengutamakan emosi atau perasaan pembaca." Tim Edukasi (KTSP, 2006:169). Salah satu ciri khas paragraf persuasi adalah menggunakan kata-kata yang bersifat ajakan/bujukan seperti: "marilah" atau "ayolah" yang didalam Teks persuasi tersebut dapat meyakini pembaca dengan argumen atau alasan yang tepat.

Keterampilan menulis dalam kurikulum 2013 untuk jenjang SMP dikembangkan secara terpadu dengan keterampilan mendengarkan, membaca, berbicara dan menulis . Menulis sebagai upaya terakhir dari rangkaian kegiatan mendengarkan teks, menanggapi isi teks, dan membaca teks. Pembelajaran Bahasa Indonesia selalu mengacu pada teks. Untuk itu, diperlukan jenis teks persuasif untuk menjadi bahan kajian. Berdasarkan hasil observasi dan wawancara dengan guru Bahasa dan Sastra Indonesia di kelas VIII SMP Negeri 3 Rantau Utara Kabupaten Labuhanbatu yang telah menerapkan Kurikulum 2013, diketahui bahwa kemampuan peserta didik dalam menulis teks persuasif masih perlu ditingkatkan. Hal ini terlihat dari 50\% peserta didik mampu menulis teks persuasif dengan baik dan benar. Peserta didik mengalami kesulitan dalam menuangkan ide atau gagasan menjadi sebuah bentuk tulisan. Hal ini disebabkan oleh faktor dalam diri peserta didik seperti sikap malas dalam menulis, ataupun faktor yang berasal dari luar seperti kurangnya latihan menulis dan kurangnya bahan ajar untuk menulis.

Untuk mencapai kemampuan maksimal dalam berpikir kritis, pola pembelajaran pun harus diubah dari Pembelajaran tradisional ke Pembelajaran modern, dari Pembelajaran yang berpusat pada guru ke Pembelajaran yang berpusat pada siswa. Siswa harus didorong untuk belajar secara mandiri dan bertanggung jawab. Siswa diberi kesempatan untuk merancang, melaksanakan, serta menilai keberhasilan belajar yang telah dilaksanakannya secara mandiri. Jika siswa selalu berpikir kritis, siswa akan mempertimbangkan tingkah laku yang diambilnya secara matang. Pertimbangan itu mencakup kebaikan dan kejelekan dari suatu perbuatan. Jika itu dilakukan, maka siswa akan melakukan hal-hal yang baik dan menghindari hal-hal yang jelek.

Rendahnya hasil belajar siswa dalam menulis teks Persuasif siswa ini disebabkan guru yang mengajarkan kemampuan menulis umumnya jarang menggunakan metode pembelajaran yang menarik minat siswa dan cenderung menjelaskan melalui metode ceramah. Hal ini membuat siswa sulit untuk menuangkan ide ke dalam bentuk tulisan serta merangkai kalimat demi kalimat menjadi sebuah paragraf yang utuh. Sehingga siswa menjadi jenuh dan minat menulis pun rendah. Kebanyakan penerapan metode dalam pembelajaran ini adalah siswa berlatih untuk meningkatkan kemampuan menulisnya hanya dengan menuliskan apa yang mereka tahu saja tanpa diberikan arahan yang menarik siswa untuk berfikir secara logis dan sistematis.

Berdasarkan keberhasilan Pembelajaran karena adanya metode yang efektif dan pendekatan saintifik, maka peneliti tertarik memilih judul 
Available online at http://jurnal.goretanpena.com/index.php/JSSR

sebagaimana yang tertulis diatas. Pendekatan Saintifik di dilakukan untuk mengembangkan bahan ajar menulis teks persuasif. Penerapan pendekatan ini diharapkan akan meningkatkan kemampuan menulis teks persuasif pada siswa kelas VIII SMP Negeri 3 Rantau Utara Kabupaten Labuhanbatu pada Tahun Pelajaran 2018/2019.

\section{METODE}

Metode yang digunakan dalam penelitian ini adalah metode Penelitian Pengembangan (Research \& Development). Metode Penelitian dan Pengembangan (Research \& Development) adalah metode Penelitian yang digunakana untuk menghasilkan produk tertentu dan menguji keefektifannya. Menurut Borg and Gall dalam Sugiyono (2009:407) yang dimaksud dengan model Penelitian dan Pengembangan adalah "a process used develop and validate educational product". Jadi, Penelitian Pengembangan sebagai usaha untuk mengembangkan dan memvalidasi produk-produk yang digunakan dalam proses Pembelajaran.

Berikut merupakan sepuluh langkah yang terdapat dalam prosedur Penelitian Pengembangan menurut Sugiyono (2009:407) yang telah dirangkum dalam skema.

\section{HASIL DAN PEMBAHASAN}

\section{Hasil Koesioner}

Koesioner analisis kebutuhan terdiri dari dua puluh pernyataan. Kuesioner terbagi dalam dua bagian, bagian pertama terdapat sepuluh butir pernyataan dengan alternatif jawaban ya dan tidak. Bagian pertama tersebut menggali informasi yang meliputi :

1. pernyataan tentang tujuan dan manfaat pembelajaran menulis teks persuasif,

2. pernyataan tentang penggunaan Pendekatan Saintifik,
3. pernyataan tentang minat siswa dalam pembelajaran menulis,

4. pernyataan tentang kebutuhan siswa dalam pembelajaran menulis teks persuasif .

Bagian kedua menggali informasi tentang :

1. pernyataan tentang menulis teks persuasif yang dialami siswa,

2. pernyataan tentang factor yang berpengaruh dalam pembelajaran menulis,

3. pernyataan tentang desain materi yang diinginkan siswa,

4. pernyataan yang berkaitan dengan topik pembelajaran menulis.kuesioner diberikan kepada siswa kelas VIII 1 SMP Negeri 3 Rantau Utara. Dengan jumlah siswa 32 orang.

Hasil wawancara dengan guru mengenai pembelajaran menulis dapat disimpulakan bahwa pembelajaran menulis teks persuasif oleh siswa memerlukan pembelajaran yang dapat memunculkan motivasi siswa dalam menulis. Hal ini erat kaitannya dengan penggunaan pendekatan saintifik karena siswa dapat bekerjasama bersama anggota kelompoknya sehingga dapat memotivasi siswa dalam menulis. Dengan demikian, hasil wawancara tersebut dapat menjadi salah satu dasar dalam penyusunan materi pembelajaran menulis teks persuasif.

Setelah saya melakukan penelitian di sekolah yang saya teliti, maka saya dapat menyimpulkan bahwa materi persuasif ini kurang dipahami oleh siswa di kelas VIII ini, dan saya membuat modul/bahan ajar yang versi saya sendiri. Dan Alhamdulillah bahan ajar yang saya buat mudah dipahami oleh siswa-siswi tersebut, karena bahasa yang saya pakai adalah bahasa yang mudah dipahami oleh siswa, berbeda dengan bahasa yang ada didalam buku paket siswa tersebut. Sehingga mereka lebih mudah memahami materi pelajaran yang ada di bahan ajar 
Available online at http://jurnal.goretanpena.com/index.php/JSSR

saya dibandingkan dengan dari buku paket mereka.

begitu juga dengan contoh-contoh yang saya lampirkan di bahan ajar saya, sangat mudah mereka pahami karena contoh yang saya pakai saya ambil dari kegiatan sehari-hari yang sering kita lalui.

Dan dengan itu siswa-siswa tersebut menjadi lebih mudah untuk memberikan contoh persuasif lainnya.

Berdasarkan pada hasil penilaian dan komentar dari dosen serta guru Bahasa Indonesia, peneliti melakukan revisi produk materi pembelajaran menulis teks persuasif. Hasil revisi meliputi : 1) perumusan tujuan pembelajaran san indikator. Penulisan tujuan pembelajaran dan indikator perlu merumuskan dengan baik dan benar. Penulisan tersebut harus dirumuskan menggunakan A B C D (Audience, Behavior, Condiontion, Degree). 2) penggunaan ejaan perlu diperhatikan seperti penggunaan tanda titik dan huruf kapital. 3) materi yang disampaikan tidak perlu diulang dua kali, materi tersebut berupa pengertian menulis.

Hasil dari penilaian dosen dan guru Bahasa Indonesia dapat menjadi pedoman untuk memperbaiki produk materi pembelajaran menulis teks persuasif agar produk menjadi lebih layak dan sempurna. Sesuai dengan hasil penilaian dan komentar dari dosen dan guru Bahasa Indonesia, peneliti telah merevisi mengenai penulisan tujuan dan indikator yang telah dirumuskan. Selain itu, penulis juga telah merevisi penggunaan ejaan yang belum tepat seperti penggunaan tanda titik dan penulisan yang masih belum lengkap. Materi yang diperbaiki yaitu penjelasan mengenai pengertian menulis tidak dituliskan dua kali. Revisi yang telah di lakukan diharapkan memperoleh hasil akhir produk materi pembelajaran yang telah sempurna.

\section{SIMPULAN}

Pengembangan

materi pembelajaran menulis teks persuasif dengan pendekatan saitifik di nilai melalui lembar penilaian yang dilakukan oleh dosen Bahasa Indonesia dan guru Bahasa Indonesia kelas VIII SMP Negeri 3 Rantau Utara. Berdasrkan hasil penilaian dan komentar yang dilakukan dosen dan guru, terdapat beberapa yang perlu direvisi yaitu : kesesuaiaan indikator dengan kompetensi dasar, perumusan dalam penulisan tujuan pembelajaran harus menggunkan formula A B C D ( Audience, Behavior, Cobdition, Degree ) dan penggunaan ejaan perlu diperbaiki. Hasil penilaian tingkat kelayakan materi pembelajaran menulis teks persuasif dengan pendekatan saintifik ini adalah 75 $\%$ ( baik ). persentase penilaian materi pembelajaran menulis teks persuasif dengan pendekatan saintifik memiliki tingkat kelayakan yang baik dan dapat di terima. Maka dari itu, hasil penilaian dan komentar dari dosen dan guru perlu di kaji untuk merevisi komponen materi pembelajaran menulis yang belum memenuhi kriteria. Revisi yang dilakukan bertujuan untuk meningkatkan kelayakan materi pembelajaran teks persuasif dengan pendekatan saintifik.

Produk yang dihasilkan dalam penelitian pengembangan ini adalah materi pembelajaran menulis teks persuasif dengan pendekatan saintifik pada siswa kelas VIII SMP Negeri 3 Rantau Utara yang didasarkan pada hasil analisis kebutuhan siswa. Produk materi pembelajaran menulis teks persuasif ini terdiri dari beberapa komponen : 1) indikator, 2) tujuan pembelajaran, 3) uraian materi, 4) kegiatan pembelajaran , dan 5) latihan. Dalam produk materi pembelajaran menulis, penulis menguraikan materi dan beberapa kegiatan yang menekankan pada kegiatan individu ataupun kelompok yang disesuaikan dengan analisis kebutuhan. 
Available online at http://jurnal.goretanpena.com/index.php/JSSR

\section{DAFTAR PUSTAKA}

Akhmadi, Agus. (2007).Pendekatan saintifik. Yogyakarta: Mitra Gama Widya. Alfabeta.

Alwasilah dan Senny. (2007). Pokoknya menulis. Bandung: PT. Kiblat Buku

Arikunto, Suharsimi. (2014). Prosedur penelitian, Jakarta: Rineka Cipta. Bandung: Angkasa.

Daryanto. (2014). Pendekatan Pembelajaran Saintifik Kurikulum 2013.

Hanafiah, N. (2009). Konsep Strategi Pembelajaran. Bandung: PT Refika Aditama.

Heriawan, (2012). Metodologi Pembelajaran. SerangBanten: LP3G.

Iskandar, Dadang. (2015). Penelitian Tindakan Kelas dan Publikasinya. Jawa Tengah: Ihya Media.Ismawati, Esti.(2012). Telaah kurikulum atau pengembangan bahan ajar.

Majid, Abdul. (2014). Implementasi Kurikulum 2013. Bandung: Interes Media

Mulyasa.(2013). Pengembangan dan implementasi kurikulum 2013. Bandung : Remaja Rosdakarya.

Nurhida Yanti. (2012). Penerapan pendekatan untuk meningkatkan hasil belajar siswa kelas IV. Skripsi pada FKIP UNPAS. BandungNurrudin.(2007). Dasardasar penulisan. Malang: UMM Press.

Nursisto. (1999) Penuntun mengarang. Bandung : Rosda.
Rusman. (2012). Model-model pembelajaran. Jakarta: Raja Grafindo Persada.

Sagala, (2010). Konsep dan makna pembelajaran. Bandung: Alfabeta.

Sambas, D. L. (2010). Upaya meningkatkan kemampuan menulis karangan persuasi. Bandung : Angkasa.

Sanjaya, W. (2010). Strategi pembelajaran Berorientasi Standar Proses Pendidikan. Jakarta: Prenada media Group.

Sudjana, Nana. (2011). Penilaian Hasil Proses belajar Mengajar. Bandung: PT Remaja Rosdakarya.

Sudjana,Nana. (2009). Penilaian Hasil proses Belajar Mengajar. Bandung: Remaja Rosdakarya.

Sugihartono, dkk. (2007). Psikologi Pendidikan. Yogyakarta: UNY Press

Sugiyono.(2016). Metode penelitian kuantitatif, kualitatif, dan $R \& D$. Bandung :

Suharsimi Arikunto. (2006). Penelitian Tindakan Kelas (Classroom Action Research). Jakarta: Bumi Aksara

Suyatno. (1977). Menjelajah Pembelajaran Inovatif. Sidoarjo: Masmedia Buana Pustaka

Syah, Darwan, dkk. (2009). Strategi Belajar Mengajar. Jakarta: Diadit Media.

Tarigan, Henry Guntur.(1999). Menulis sebagai suatu keterampilan berbahasa.

Trianto. (2010). Mendesain Model Pembelajaran Inovatif-Progresif. 